\title{
Analgesic Effect of Bangle Rhizome Ethanol Extraction on Thermally Induced Pain in Mus musculus
}

\author{
Margareth Ayu Caroline Pangkerego', Hamzah², Danti Nur Indiastuti ${ }^{3 *}$ \\ ${ }^{1}$ Faculty of Medicine, Universitas Airlangga, Surabaya, Indonesia \\ ${ }^{2}$ Department of Anesthesiology and Reanimation, Faculty of Medicine, Universitas Airlangga, Surabaya, Indonesia - Dr. \\ Soetomo General Hospital Surabaya, Indonesia \\ ${ }^{3}$ Department of Pharmacology, Faculty of Medicine, Universitas Airlangga, Surabaya, Indonesia
}

\section{A R T I C L E I N F O}

\section{Article history:}

Received 25 September 2019

Received in revised form 14

October 2019

Accepted 18 October 2019

Available online 31 October 2019

\section{Keywords:}

Zingiber cassumunar Roxb.,

Hot plate method,

Analgesic,

Thermal pain.

\section{*) Corresponding author:}

dantinurindiastuti@gmail.com

\begin{abstract}
A B S T RACT
Introduction: Pain causes deterioration of quality of life. Nonsteroidal anti-inflammatory drug (NSAID) is used to relieve pain with upper gastrointestinal side effects. Zingiber cassumunar Roxb. (known as bangle) is commonly used to relieve pain, but no study has been proved to have analgesic effect. In empirical study, bangle is a potential analgesic due to its bioactive compound named zerumbone. The aim of this study was to investigate the analgesic effect of bangle rhizome ethanol extraction on thermally induced pain.

Methods: Five groups of male Mus musculus consisting of 6 mice each were used. A single dose of bangle extract $2 \mathrm{mg} / 20 \mathrm{~g}, 4 \mathrm{mg} / 20 \mathrm{~g}, 8 \mathrm{mg} / 20 \mathrm{~g}$, aspirin $1.82 \mathrm{mg} / 20 \mathrm{~g}$, and aquadest $0.2 \mathrm{ml}$ were administrated. The analgesic effect was evaluated by hot plate test. The test was evaluated at $15^{\text {th }}$, $30^{\text {th }}, 45^{\text {th }}$ minute. Latency period was observed when mice showed pain responses including hind paw shaking, hind paw licking or jumping. The data was analyzed by paired T-test and one-way ANOVA.

Results: Results showed that all doses of bangle extract and aspirin $1.82 \mathrm{mg} / 20 \mathrm{~g}$ produced significant latency period $(\mathrm{p}<0.05)$ compared to baseline in each group using paired T-test. Latency period of bangle extract $8 \mathrm{mg} / 20 \mathrm{~g}$ was more significant than bangle extract $2 \mathrm{mg} / 20 \mathrm{~g}$ and $4 \mathrm{mg} / 20$ g. One-way ANOVA showed no significant difference in latency period $(\mathrm{p}=0.1)$ between bangle extract and aspirin $(\mathrm{p}>0.05)$.

Conclusion: Bangle extract has analgesic effect on thermally induced pain. The minimum dose for analgesic is $2 \mathrm{mg} / 20 \mathrm{~g}$ or potentially less.
\end{abstract}

\section{Introduction}

Pain is unpleasant sensory and emotional sensation resulting in potential tissue damage. Pain is subjective. Each individual experiences pain differently due to psychological, social, threshold, and tolerance level ${ }^{1}$. Pain causes deterioration in patient's quality of life by limiting social contacts, leisure activities, abstinence from work and early retirement, disability, or mortality in several cases ${ }^{2}$.

Nonsteroidal anti-inflammatory drug (NSAID) is used to relieve pain and inflammation. NSAID is commonly used in Indonesia, mainly in East Java (15\%). Long term usage of NSAID results in gastrointestinal bleeding and ulceration ${ }^{3}$. Therefore, an adjuvant to analgesic is needed.

Zingiber cassumunar Roxb. (known as bangle) is part of the Zingiberaceae family and commonly used as herbal medicine in Indonesia. The Zingiberaceae family, including bangle, has mutual bioactive compound named zerumbone. Zerumbone mechanism in inhibition of pain is the same as aspirin. It inhibits capsaicin, a compound that activates TRPV-1 receptor, resulting in no impulse transmission to the spinal cord. Zerumbone also inhibits COX-2. In peripheral, it inhibits COX-2 released by arachidonic acid on membrane cell. In central, it inhibits COX-2 released by $1^{\text {st }}$ order neuron on the dorsal horn of spinal cord. This theory is supported by recent studies that showed Zingiber officinale (ginger) and Zingiber zerumbet (lempuyang) had analgesic effect on thermally induced pain ${ }^{4,5,6}$. However, the analgesic effect of bangle on thermally induced pain has never been studied.

Moreover, recent study showed that bangle also has gastric ulcer healing effect induced by aspirin. Bangle reduced the diameters of ulcer. Histopathological data also showed reduction of edema and inflammation area in stomach tissue. This was due to bioactive compounds named flavonoids and curcuminoids. It had antioxidant 
that reduced free radical formation ${ }^{17}$. Thus, the capsaicin inhibitor and gastric ulcer healing effect make Bangle a potential adjuvant for pain relief.

The aim of this study was to investigate the analgesic effect of ethanol extract of Bangle in thermally induced pain.

\section{Methods}

\section{Ethical clearance}

This in-vivo study has been approved by Ethical Review Committee, Faculty of Medicine, Universitas Airlangga, Surabaya.

\section{Plant material and extraction}

Bangle rhizome powder was acquired from Balai Materia Medica Batu (MMB). A $100 \mathrm{~g}$ powder was soaked in 70\% ethanol in a closed container for 24 hours prior filtration using Value 1 Stage Vacuum Pump. The procedure was repeated 3 times. The filtrate later evaporated by Buchi Recirculating Chiller F-305 for 24 hours, resulting in a 10 $\mathrm{g}$ of jelly texture extract. The extract was stored at $4^{\circ} \mathrm{C} 18$.

\section{Suspension}

Bangle rhizome extract $4 \mathrm{~g} / 100 \mathrm{ml}$ was diluted in hot water and 1\% CMC Na (PT Brataco), resulting in a 100 $\mathrm{ml}$ suspension dose $8 \mathrm{mg} / 20 \mathrm{~g}$. Half of this suspension was diluted in the same viscosity modifier, resulting in a $100 \mathrm{ml}$ suspension dose $4 \mathrm{mg} / 20 \mathrm{~g}$. This procedure was repeated until resulting in a $100 \mathrm{ml}$ suspension dose $2 \mathrm{mg} / 20 \mathrm{~g}$.

\section{Animal Model}

Thirty male Mus musculus were acquired from Pusat Kampung Mitra Jombang and were acclimated at Pharmacology Laboratory, Universitas Airlangga. All mice had to meet specific body weight (20-30 g) and specific age (8-12 weeks). Mice were divided into 5 identical cages and stored at room temperature $\left(30-35^{\circ} \mathrm{C}\right)$. All mice were fed with standard diet and had $12 \pm 1$ day/night schedules ${ }^{19}$.

\section{Experimental Design}

This study used 30 male Mus musculus. Subjects were divided into 5 groups, consisting of 6 mice each. Each group received different treatment. Baseline was measured 2 days prior drug treatment to prevent memory pain and inflammation of the hind paw. Group I to group III received a single dose of ethanol extract of Bangle rhizome at doses $2 \mathrm{mg} / 20 \mathrm{~g}, 4 \mathrm{mg} / 20 \mathrm{~g}$, and $8 \mathrm{mg} / 20 \mathrm{~g}$. Group IV received a single dose of aspirin $1,82 \mathrm{mg} / 20 \mathrm{~g}$ as positive control. Group $\mathrm{V}$ received aquadest $0,2 \mathrm{ml}$ as placebo. All drugs were administrated 15 minutes prior hot plate exposure. This was due to peak plasma concentration of aspirin which approximately was 15 minutes after administration.

Each mouse would be placed on hot plate (Ugo Basile 7280, Gemonio, Italy). The hot plate temperature was constantly set on $51^{\circ} \pm 0.1^{\circ} \mathrm{C}$. Latency period was recorded by one observer at 15 th, 30th, 45 th minute to reduce personal bias. Latency period showed the time needed for subject to give pain responses including hind paw shaking, hind paw licking or jumping. All test must not exceed 30 seconds.

\section{Data Analysis}

Data was analyzed with IBM SPSS Statistics Subscription 16 th version. The software ran description, normality, homogeneity test, and compare means. Comparison of homogenous data and normal distribution $(p>0,05)$ was measured by one-way ANOVA and paired T-test. A value of $\mathrm{p}<0.05$ was considered significant. Significant results were followed by Least Significant Difference (LSD) test.

\section{Results}

These are results for hot plate test to determine analgesic effect of bangle on thermally induced pain. Data was collected in 3 different periods (15th, 30th, 45 th minute after drugs administration) and the mean value was determined. Post-treatment had longer latency period than baseline in every group. The mean value of baseline ranged from 20 to 23 seconds, while post-treatment ranged from 25 to 36 seconds. The standard deviation in all groups were smaller than the mean, meaning that the data was less varied (table 1).

The minimum and maximum latency period were also analyzed. The minimum and maximum values showed the fastest and slowest latency period. The negative value in group II and group V indicated longer latency period in baseline than post-treatment (table 1).

Table 1. Mean value of the latency period in male mice (Mus musculus) using the hot plate method.

\begin{tabular}{llllll}
\hline & Group & Min(s) & Max(s) & Baseline(s) & $\begin{array}{c}\text { Post- } \\
\text { Treatment } \\
\text { (s) }\end{array}$ \\
\hline I & $\begin{array}{l}\text { B angle } \\
\text { 2mg/20g }\end{array}$ & 2.27 & 22.03 & $20.55 \pm 4.62$ & $33.19 \pm 7.21$ \\
& & & & & \\
\hline II & $\begin{array}{l}\text { B angle } \\
\text { 4mg/20g }\end{array}$ & -0.63 & 20.50 & $23.69 \pm 5.38$ & $36.79 \pm 1.21$ \\
\hline III & $\begin{array}{l}\text { B angle } \\
\text { 8mg/20g }\end{array}$ & 5.47 & 25.02 & $20.54 \pm 5.95$ & $35.57 \pm 1.02$ \\
\hline IV & $\begin{array}{l}\text { Aspirin0,4 } \\
\text { mg/20g }\end{array}$ & 4.97 & 23.70 & $21.41 \pm 4.72$ & $35.11 \pm 7.43$ \\
\hline V & $\begin{array}{l}\text { Aquadest } \\
0,2 m l\end{array}$ & -7.03 & 11,92 & $22.83 \pm 2.95$ & $25.29 \pm 6.55$ \\
\hline
\end{tabular}

The mean value was further used to analyze data distribution and homogeneity. All data was normally distributed $(p>0.05)$ and homogeneous $(p=0.711)$.The mean value of baseline and post-treatment in each group were compared using paired T-test. The result showed that group I to IV had significant difference between baseline and post-treatment $(\mathrm{p}<0.05)$ (table 2$)$.

Table 2. Comparison of baseline and post-treatment latency period in each group (paired T-test).

\begin{tabular}{llc}
\hline & \multicolumn{1}{c}{ Group } & Significance (p) \\
\hline I & Bangle $2 \mathrm{mg} / 20 \mathrm{~g}$ & $0.039^{*}$ \\
\hline II & Bangle $4 \mathrm{mg} / 20 \mathrm{~g}$ & $0.009^{*}$ \\
\hline III & Bangle $8 \mathrm{mg} / 20 \mathrm{~g}$ & $0.007^{*}$ \\
\hline IV & Aspirin $0,4 \mathrm{mg} / 20 \mathrm{~g}$ & $0.003^{*}$ \\
\hline V & Aquadest $0,2 \mathrm{ml}$ & 0.474 \\
\hline
\end{tabular}

The one-way ANOVA test showed that there was no significant difference between 5 groups $(p=0.1)$.

\section{Discussion}

The results showed no significant difference in latency periods between 5 groups, suggesting that bangle inhibited 
thermally induced pain. All doses of bangle and aspirin 1.82 $\mathrm{mg} / 20$ had a significant difference in latency period between baseline and post-treatment in each group, meaning that latency period was longer after being treated with bangle or aspirin. This indicated that bangle extract had minimum analgesic effect at dose $2 \mathrm{mg} / 20 \mathrm{~g}$ or less. Studies showed that lempuyang extract had significant difference starting from the dose of $2 \mathrm{mg} / 20 \mathrm{~g}$, while dose $6 \mathrm{mg} / 20 \mathrm{~g}$ had comparable analgesic effect to morphine $5 \mathrm{mg} / \mathrm{kg}^{9}$. In contrast, ginger extract $4 \mathrm{mg} / 20 \mathrm{~g}$ had comparable analgesic effect to aspirin, which was twice larger than bangle and lempuyang extract. ${ }^{10}$

Bangle rhizome extract consists of bioactive compound named sabinene, 4-ol terpineol, sesquiphellandrene, $\beta$-pinene, cassumunarin $\mathrm{B}$, cassumunarin $\mathrm{C}$, myrcene, (E)-1-(3,4-dimethoxyphenyl)but-1-ene, (E)-1-(3,4dimethoxyphenyl), butadiene, caryophyllene, and zerumbone6. Zerumbone inhibits capsaicin, a compound that activates TRPV-1 receptor. Consequently, thermal pain transmission is restricted to the brain.?

Zerumbone is also found in ginger and lempuyang extract. ${ }^{9,10}$ The amount of zerumbone differs in each species: Bangle extract $(0.6 \%)$, ginger extract (37\%), and lempuyang extract $(69.9 \%))^{4,9,12}$ However, bangle has lower minimum dose of analgesic than ginger. ${ }^{9,10}$ It is possible that there are other compounds which contribute as analgesic on thermally induced pain.

Another compound in Zingiberaceae family is (E)-4(3',4'-dimethoxyphenyl)but-3-en-2-ol (compound D). This compound had been shown to provide anti-inflammatory effects by inhibiting COX-2.,13 There was significant difference between Compound D and negative control on tail flick test. It showed that compound D acted as central analgesic although it was weak compared to morphine. Moreover, another study showed no significant difference between compound $\mathrm{D}$ and aspirin in writhing test. It showed that compound $\mathrm{D}$ could also act as peripheral analgesic effect and was comparable to aspirin. ${ }^{14}$ Therefore, it is possible that zerumbone and compound D work synergistically as analgesic in thermally induced pain.

All doses of bangle are safe for single and repeated doses. Recent studies showed that a single dose of bangle extract $118 \mathrm{mg} / \mathrm{kg}$ and repeated doses of $500 \mathrm{mg} / \mathrm{kg} /$ day did not cause death and abnormal clinical signs for 90 days. ${ }^{15,16}$ This also proved bangle is safer than a single dose of ginger extract $2500 \mathrm{mg} / \mathrm{kg}$ that causes severe hypotension and bradycardia. ${ }^{16}$

All doses of bangle extract in this study showed significant results, but it did not determine the lowest dose. Therefore, further study is needed to define the exact minimum dose of bangle extract as analgesic. Furthermore, other potential bioactive compounds in bangle shall be explored for adjuvant analgesic.

\section{Conclusion}

Bangle extract had analgesic effect on thermally induced pain in male Mus musculus which was derived from zerumbone and potentially compound D. The lowest bangle extract dose in this study $(2 \mathrm{mg} / 20 \mathrm{~g})$ showed analgesic effect. It is potential that the minimum dose of bangle extract for analgesic is lower than $2 \mathrm{mg} / 20 \mathrm{~g}$.

\section{Conflict of Interest}

The author stated there is no conflict of interest

\section{References}

1. Merskey H, Bogduk N. Classification of Chronic Pain, IASP Task Force on Taxonomy. 2nd ed. Seattle: IASP Press; 1994.

2. Duenas M, Ojeda B, Salazar A, Mico J, Failde I. A review of chronic pain impact on patients, their social environment and the health care system. Journal of Pain Research. 2016; Volume 9:457-467.

3. Soleha M, Isnawati A, Fitri N, Adelina R, Soblia H, Winarsih W. Profil Penggunaan Obat Antiinflamasi Nonstreoid di Indonesia. Jurnal Kefarmasian Indonesia. 2018;8(2):109-117.

4. Ozaki Y, Kawahara N, Harada M. Anti-inflammatory Effect of Bangle and Its Active Principles. Chemical \& Pharmaceutical Bulletin. 1991;39(9):2353-2356.

5. Masuda T, Jitoe A. Antioxidative and Antiinflammatory Compounds from Tropical Gingers: Isolation, Structure Determination, and Activities of Cassumunins A, B, and C, New Complex Curcuminoids from Z. cassumunar. Journal of Agricultural and Food Chemistry. 1994;42(9):1850-1856.

6. Singh P, Kongara K, Harding D, Ward N, Dukkipati V, Johnson C et al. Comparison of electroencephalographic changes in response to acute electrical and thermal stimuli with the tail flick and hot plate test in rats administered with opiorphin. BMC Neurology. 2018;18(1).

7. Perimal E, Akhtar M, Mohamad A, Khalid M, Ming O, Khalid S et al. Zerumbone-Induced Antinociception: Involvement of the 1-ArginineNitric Oxide-cGMP -PKC-K+ATP Channel Pathways. Basic \& Clinical Pharmacology \& Toxicology. 2010;108(3):155-162.

8. Koparde A, Magdum C, Doijad R. Evaluation of Synergistic In vitro Anti-inflammatory Activity of Eulophia ochreata Lindl and Bangle Research Journal of Pharmacy and Technology. 2018;11(11):5053.

9. Sulaiman M, Perimal E, Zakaria Z, Mokhtar F, Akhtar M, Lajis N et al. Preliminary analysis of the antinociceptive activity of zerumbone. Fitoterapia. 2009;80(4):230-232.

10. Mantiri N, Awaloei H, Posangi J. Perbandingan Efek Analgesik Perasan Rimpang Jahe Merah (Z. officinale var. rubrum Thelaide) Dengan Aspirin Dosis Terapi pada Mencit (Mus musculus). Jurnal e-Biomedik. 2013;1(1)

11. Jia Y, Zhao J, Zhang L, Sun B, Bao M, Li F, et al. Analgesic and Anti-inflammatory Effects of Ginger Oil. Chinese Herbal Medicines. 2011;3(2):150-155.

12. Sharifi-Rad M, Varoni E, Salehi B, Sharifi-Rad J, Matthews K, Ayatollahi S et al. Plants of the Genus Z. as a Source of Bioactive Phytochemicals: From Tradition to Pharmacy. Molecules. 2017;22(12):2145.

13. Lim T. Edible Medicinal and Non-medicinal Plants. New York: Springer; 2016

14. Panthong A, Kanjanapothi D, Niwatananant W, Tuntiwachwuttikul P, Reutrakul V. Anti-inflammatory activity of compound D $\left\{(\mathrm{E})-4-\left(3^{\prime}, 4^{\prime}-\right.\right.$ dimethoxyphenyl)but-3-en-2-ol $\}$ isolated from Bangle Phytomedicine. 1997;4(3):207-212.

15. Kato E, Kubo M, Okamoto Y, Matsunaga Y, Kyo H, Suzuki N et al. Safety Assessment of Bangle (Z. purpureum Rosc.) Rhizome Extract: Acute and Chronic Studies in Rats and Clinical Studies in Human. ACS Omega. 2018;3(11):15879-15889.

16. Elkhishin I, Awwad I. A Study of The Cardiovascular Toxic Effects of Z. officinale (Ginger) in Adult Male Albino Rats and its Possible Mechanisms of Action. Mansoura Journal of Forensic Medicine \& Clinical Toxicology. 2009.

17. Yuniarto A, Susilawati E, Rahman T, Setiawan F, Juanda D. Gastric Ulcer Healing Effect of Bangle (Zingiber cassumunar (Roxb.)) Rhizome Extract in Aspirin-induced Rats Model. Indonesian Journal of Pharmaceutical Science and Technology. 2017;1(1):29.

18. Wulansari E, Wahyuono S, Marchaban, Widyarini S. Potential Bengle (Zingiber cassumunar Roxb.) Rhizomes For Sunscreen and Antioxidant Compounds. International Journal of PharmTech Research. 2016;9(11):72-77.

19. Dita M, Mukono I, Rochmanti M. Combination Effect of The Extract Avocado Leaf and Seed (Persea Americana) on Level of Total Cholesterol, LDL, and HDL in Mice (Mus musculus) with Hypercholesterolemia. Biomolecular and Health Science Journal. 2019;2(1):45. 